\title{
Efficiency of transgene expression in bovine cells varies according to cell type and gene transfer method ${ }^{x}$
}

\author{
La eficiencia de la expresión transgénica en células bovinas varía según el tipo de célula y el método de \\ la transferencia de genes
}

\section{A eficiência da expressão do transgene em células bovinas varia de acordo com o tipo celular e o método de transferência gênica}
Alinne G Curcio ${ }^{1 *}$, MV, MSc; Fabiana F Bressan ${ }^{2}, \mathrm{MV}, \mathrm{PhD}$; Carla S Paes De Carvalho ${ }^{1}$, MV, PhD; Célia R Quirino ${ }^{1}$; Eng Agr, PhD; Flavio V Meirelles ${ }^{2}, \mathrm{MV}, \mathrm{PhD}$; Angelo J B Dias ${ }^{1}, \mathrm{MV}, \mathrm{PhD}$.
${ }^{1}$ Laboratório de Reprodução e Melhoramento Genético Animal,
Centro de Ciências e Tecnologias Agropecuárias, Universidade Estadual do Norte Fluminense Darcy Ribeiro - UENF, Campos dos Goytacazes, Rio de Janeiro, Brasil.

${ }^{2}$ Departamento de Medicina Veterinária, Faculdade de Zootecnia e Engenharia de Alimentos, Universidade de São Paulo - USP, Duque de Caxias Norte, 225, Pirassununga, São Paulo, Brasil.

(Received: January 25, 2017; accepted: April 24, 2018)

doi: 10.17533/udea.rccp.v32n1a04

\begin{abstract}
Background: Production of transgenic animals is still a low-efficiency biotechnology, and simple alternatives should be used to improve the rate of transgenic bovine production by nuclear transfer. One such alternative is selecting the appropriate donor cell type and transfection method. Objective: To investigate the effect of cell type (fetal or adult fibroblasts, and cumulus cells), and gene transfer method (lipofection and lentiviral transduction) on the incorporation, expression, and fluorescence intensity of transgene on bovine cells analyzed by flow cytometry. Methods: Fetal fibroblasts (FF), adult fibroblasts (AF), and cumulus cells (CC) were transfected using lipofection, or transduced using lentiviral particles produced with Green Fluorescent Protein (GFP) expressing plasmids, and analyzed by flow cytometry.
\end{abstract}

a To cite this article: Curcio AG, Bressan FF, Paes De Carvalho CS, Quirino CR, Meirelles FV, Dias AJB. Efficiency of transgene expression in bovine cells varies according to cell type and gene transfer method. Rev Colomb Cienc Pecu 2019; 32(1):34-42.

* Corresponding author: Alinne Gloria Curcio. Laboratório de Reprodução e Melhoramento Genético Animal, Centro de Ciências e Tecnologias Agropecuárias, Universidade Estadual do Norte Fluminense Darcy Ribeiro - UENF, Avenida Alberto Lamego, 2000. Parque Califórnia, Campos dos Goytacazes, Rio de Janeiro, Brasil. Tel.: 5522 27397235. E-mail: alinne_gloria@hotmail.com 
Results: Lentiviral transduction resulted in higher transgene expression rates for all cell types (FF: $88.8 \pm$ 0.98; AF: $91.6 \pm 2.96$; CC: $60.7 \% \pm 14.7$ ) compared to lipofection (FF: $17.8 \pm 2.82$; AF: $10.66 \pm 0.65$; CC: $3.9 \% \pm 1.97)$. Cumulus cells showed lower transgene expression rates than the other cell types. Regarding fluorescence intensity, there was no significant difference between lipofection and lentiviral transduction; in both treatments, higher fluorescence intensity was obtained when adult cells were used instead of fetal cells. Conclusion: Gene transfer efficiency varies according to cell type, and gene transfer method, with lentiviral transduction achieving higher transgene expression rate, and adult fibroblasts showing better transgene expression.

Keywords: cloning, epigenetics, lipofection, lentiviral transduction, nuclear reprogramming.

\section{Resumen}

Antecedentes: La producción de animales transgénicos sigue siendo una biotecnología de baja eficiencia, y se deberían utilizar alternativas sencillas para mejorar la tasa de producción de bovinos transgénicos mediante transferencia nuclear. Una de estas alternativas es la selección del tipo mas apropiado de célula donante y método de transferencia génica. Objetivo: Investigar el efecto del tipo celular (fibroblastos fetales o adultos, y celulas del cumulus), y el método de transferencia génica (lipofección y transducción lentiviral) en la incorporación, expresión génica, y la intensidad de fluorescencia del transgén en células bovinas analizadas por citometría de flujo. Métodos: Fibroblastos fetales (FF), fibroblastos adultos (AF), y células del cúmulo (CC) fueron transfectados a través de lipofección o transducidos utilizando partículas lentivirales producidas con plásmidos que expresan la proteína verde fluorescente (GFP). Resultados: La transducción lentiviral dio lugar a mayores tasas de expresión del transgen en todos los tipos de células (FF: $88,8 \pm 0,98$; AF: $91,6 \pm 2,96, \mathrm{CC}: 60,7 \% \pm 14,7$ ) en comparación con la lipofección (FF: 17,8 $\pm 2,82$; AF: $10,66 \pm 0,65$; CC: $3,9 \% \pm 1,97)$. Las células del cúmulus mostraron menores tasas de expresión del transgen que los otros tipos celulares. En cuanto a la intensidad de fluorescencia, no hubo diferencias significativas entre lipofección y transducción lentiviral; en ambos tratamientos, se obtuvo una mayor intensidad de fluorescencia cuando se usaron células adultas en lugar de células fetales. Conclusión: La eficiencia de la transferencia de genes varía según el tipo de célula y el método de transferencia génica, con la transducción lentiviral se logra una mayor tasa de transfección, y los fibroblastos adultos muestran una mejor expresión transgénica.

Palabras clave: clonación, epigenética, lipofección, reprogramación nuclear, transducción lentiviral.

\section{Resumo}

Antecedentes: A produção de animais transgênicos é uma biotecnologia que ainda apresenta baixa eficiência e alternativas simples devem ser usadas para o aumento da produção de bovinos transgênicos por transferência nuclear. Uma destas alternativas compreende a seleção do tipo apropriado de célula doadora de núcleo e do método de transferência gênica. Objetivo: Investigar a influência do tipo celular (fibroblastos fetais ou adultos, e células do cumulus), e do método de transferência gênica (transfecção por lipofecção ou transdução lentiviral) na incorporação, expressão, e na intensidade de fluorescência do transgene em células bovinas analisadas por citometria de fluxo. Métodos: Fibroblastos fetais (FF), fibroblastos adultos (AF), e células do cumulus $(\mathrm{CC})$ foram submetidas à lipofecção ou à transfecção lentiviral utilizando plasmídeos expressando a Proteína Fluorescente Verde - GFP). Resultados: A transdução lentiviral resultou em maiores taxas de expressão do transgene em todos os tipos celulares (FF: 88,8 $\pm 0,98 ; \mathrm{AF}: 91,6 \pm 2,96 ; \mathrm{CC}: 60,7 \% \pm$ 14.7) quando comparada com a lipofeccção (FF: 17,8 $\pm 2,82$; AF: $10,66 \pm 0,65 ; \mathrm{CC}: 3,9 \% \pm 1,97)$. As células do cumulus apresentaram menores taxas de expressão quando comparadas aos outros tipos celulares. Com relação à intensidade de fluorescência, não houve diferença significativa entre a lipofecção e a transdução lentiviral e em ambos os tratamentos as células adultas apresentaram maior intensidade de fluorescência do que as células fetais. Conclusão: A eficiência de transferência gênica varia de acordo com o tipo celular, e com o método de transferência gênica, sendo que a transdução lentiviral resultou em maiores taxas, e que os fibroblastos adultos mostraram melhor expressão do transgene.

Palavras-chave: clonagem, epigenética, lipofecção, reprogramação nuclear, transdução lentiviral. 


\section{Introduction}

The interest in genetic modification of domestic animals is largely due to the possibility of using animals as bioreactors to produce pharmaceutical proteins, such as coagulation factors (Su et al., 2015), albumin (Sheng et al,. 2016), fibroblast growth factor 2 (FGF2) (Jeon et al., 2016), and others. Transgenic bovine production could benefit from somatic cell nuclear transfer (SCNT); however, such technology still presents low efficiencies of about 1-3\% (Kues and Niemann, 2011). Cell type (Cho et al., 2004) and transgene introduction method (Cao et al., 2010) are important aspects that influence the efficiency of transgenic animal production by SCNT.

Fetal and adult fibroblasts are the cell types most commonly used in SCNT probably because these cells are easy to obtain, cultivate, and may undergo many cell divisions before reaching senescence (Bressan et al., 2008). Arat et al. (2001) showed for the first time the possibility of using granulosa cells in transgenic bovine production. Since then, different cell types, both fetal and adult, have been used as donor cells with variable efficiency (Gong et al., 2004; Feng et al., 2015). Hence, it is possible that more open chromatin configurations, such as those in fetal cells, are beneficial to transgenic production.

Gene transfer methods can be classified into transient or permanent or stable. Retroviral transduction is an example of permanent gene transfer because retroviruses use their infection machinery to integrate the transgene in a stable manner into the genome of the host cell. Using lipofection, a transient method, once inside the cell the transgene becomes dependent on cellular mechanisms to penetrate the nucleus and eventually integrate into chromosomal DNA. This process occurs spontaneously but rarely, and the integration occurs randomly, which makes the expression, when present, unpredictable, possibly causing low-efficiency transgenesis (Keravala and Calos, 2008).

There have been recent advances in the field of transgenesis, specifically endonucleases, mainly clustered regulatory interspaced short palindromic repeats (CRISPR-Cas9), which cleaves the DNA in a site-specific manner enabling to integrate a desired transgene with relatively high transgenesis efficiency (Hsu et al., 2014). Nevertheless, new technologies are still dependent on essential cellular and molecular mechanisms such as choice of cell type and the most appropriate gene transfer method. Managing these check points should improve transgenic results.

Thus, this study aimed to investigate the effect of cell type (fetal or adult fibroblasts, and cumulus cells) and gene transfer method (lipofection or lentiviral transduction) on gene incorporation, expression, and fluorescence intensity of transgene on bovine cells analyzed by flow cytometry.

\section{Materials and methods}

\section{Ethical considerations}

All cell types used in this work were obtained from bovine tissues collected from a slaughterhouse in Campos dos Goytacazes, Brazil.

\section{Reagents}

All reagents, unless otherwise specified, were obtained from Sigma (St. Louis, MO, USA).

\section{Cell culture establishment}

Fetal fibroblasts were obtained from a tissue fragment culture from the dorsal skin of 50-day fetuses, and adult fibroblasts from a subcutaneous tissue fragment culture of adult cattle ear. Collected tissues were cut into small pieces and cultured in TCM without HEPES with $10 \%$ fetal bovine serum, and $1 \%(\mathrm{v} / \mathrm{v})$ penicillin/streptomycin $(10000 \mathrm{U} / \mathrm{ml}$ penicillin $\mathrm{G}, 10000 \mathrm{mg} / \mathrm{ml}$ streptomycin) culture medium at $38.5^{\circ} \mathrm{C}$; these were placed in $35-\mathrm{mm}$ tissue culture plates and kept in a humidified atmosphere of $5 \% \mathrm{CO}_{2}$ in air until $80 \%$ confluence, approximately, was reached.

A cumulus cell culture was established by aspirating ovarian antral follicles from slaughterhouse ovaries. The follicles were transferred into $35-\mathrm{mm}$ tissue culture plates containing culture medium and then cultured for at least 24 hours. The oocytes were then removed, and the cumulus cells were cultured 
until they reached $80 \%$ confluence, approximately. The cultures from different cell types were then tripsinized with $0.25 \%$ trypsin. After two passages, the cells were frozen in TCM without HEPES, supplemented with $40 \%$ FBS and $10 \%$ dimethyl sulfoxide. Experiments were conducted with cell lines at the same or very similar $(<5)$ passages.

\section{Transgenic cell establishment}

The cells were submitted to two different gene transfer methods: lentiviral transduction (Group 1, G1), and lipofection (Group 2, G2). Lentiviral transduction (G1) was performed with lentiviral particles following the ViraPower lentiviral expression system (Life Technologies, Carlsbad, California, USA) protocol, and the FUGW (flapUb promoter-GFP-WRE) plasmid containing the reporter enhanced Green Fluorescent Protein (eGFP) gene under the control of Ubiquitin $\mathrm{C}$ promoter (constitutive expression) (Lois et al., 2002). For this, 293FT cells (Invitrogen, Carlsbad, California, USA) were transfected using Lipofectamine 2000 (Thermo Fisher Scientific, Waltham, Massachusetts, USA) with $1,2 \mu \mathrm{g}$ pLP1, and pLP2; $2,4 \mu \mathrm{g} \mathrm{pLP} /$ VSVG plasmids, and $1 \mu \mathrm{g}$ FUGW for each well of a six-well plate, in accordance to the manufacturer's instructions. Twenty-four and 48 hours after 293FT cell transfection, supernatant culture medium containing lentiviral particles was collected, filtered, and deposited on the wells containing the different cell types $(1 \mathrm{~mL} /$ well).

Lipofection (G2) was carried out using Lipofectamine 2000 (Thermo Fisher Scientific, Waltham, Massachusetts, USA) according to the manufacturer's instructions such that each well contained $1 \mu \mathrm{g}$ of FUGW plasmid. The control group was not subjected to any method of transfection. Transduction and lipofectation were performed in 6-well plates.

Fluorescence evaluation of the post-transfected cells by flow cytometry

Flow cytometry analysis was carried out 48 hours post-transfection using BD FACSAria flow cytometer and FACSDiva software (BD Biosciences, San Jose, CA, USA).
Fluorescence was excited with a 488-nm laser, and read using a 530/30-nm filter. The different cell types were identified and selected from debris by size (forward-scatter light (FSC-H)) and complexity (sidescattered light (SSC-H)) analyses. Two variables were measured by cytometric analysis: (i) the transfection efficiency (Green Fluorescent Protein positive cells GFP + cells, read by fluorescein isothiocyanate-FITCchannel), and (ii) the intensity of fluorescence emitted by GFP + cells (means of arbitrary units, FACSDiva software, BD Biosciences, San Jose, CA, USA).

Morphological evaluation of the post-transfection cells observed under light microscopy

The cells submitted to transduction or lipofection were analyzed through optical microscopy (200X) (TE300, Nikon, Osaka, Japan) 24 hours posttransfection for overall viability analysis. The presence of cellular debris, detached cells, and cytoplasmic vacuoles -considered as cell death indicators- was visually assessed.

\section{Statistical analysis}

After data consistency and descriptive statistics analysis (mean, standard deviation, and coefficient of variation), analysis of variance was used to verify differences between the cell types that underwent different treatments, and to determine if there was any interaction between the two variables. The interaction was considered significant at $p<0.05$, and analyses were done for each cell type subjected to each treatment. The means were compared by the StudentNewman-Keuls (SNK) test of SAS ${ }^{\circledR}$ software, version 6.03, 1988 (SAS Institute Inc., Cary, NC, USA).

\section{Results}

Cell type influences the transfection method efficiency

The lentiviral system was the most efficient gene transfer method (based on the percentage of cells positive for green fluorescence, GFP + ) regardless of the cell type used, with a higher number of positive cells per sample (FF 88.8\% \pm 0.98 ; AF $91.6 \% \pm 2.96$; and CC $60.7 \% \pm 14.7, \mathrm{p}<0.05)$. Among the cell types 
examined, $\mathrm{CC}$ showed the lowest $(\mathrm{p}<0.05)$ transgene expression levels, and differed from the others. The use of lipofection resulted in a significantly lower $(p<0.05)$ transfection percentage than when the lentiviral system was applied. Fetal fibroblasts presented significantly higher $(\mathrm{p}<0.05)$ transfection levels $(17.8 \% \pm 2.82)$, followed by AF $(10.66 \% \pm 0.65)$ and, finally, by CC $(3.9 \% \pm 1.97)$ (Table 1 and Figure 1$)$.

Table 1. Percentage of fetal fibroblasts (FF), adult fibroblasts (AF), and cumulus cells (CC) emitting green fluorescence (GFP+) after lentiviral transduction or lipofection to introduce the FUGW plasmid, as analyzed by flow cytometry.

\begin{tabular}{lccc}
\hline Gene transfer method & $\begin{array}{c}\text { FF\% GFP } \\
\text { (Mean } \pm \text { SD) }\end{array}$ & $\begin{array}{c}\text { AF\% GFP } \\
\text { (Mean } \pm \text { SD) }\end{array}$ & $\begin{array}{c}\text { CC\% GFP }^{+} \\
\text {(Mean } \pm \text { SD) }\end{array}$ \\
\hline Lentiviral & $88.8 \pm 0.98^{\mathrm{Aa}}$ & $91.6 \pm 2.96^{\mathrm{Aa}}$ & $60.7 \pm 14.7^{\mathrm{Ab}}$ \\
Lipofection & $17.8 \pm 2.82^{\mathrm{Ba}}$ & $10.66 \pm 0.65^{\mathrm{Bb}}$ & $3.9 \pm 1.97^{\mathrm{Bc}}$ \\
Control & $0.15 \pm 0.07^{\mathrm{Ca}}$ & $0.15 \pm 0.07^{\mathrm{Ca}}$ & $0.05 \pm 0.07^{\mathrm{Ca}}$ \\
\hline
\end{tabular}

Means followed by the same uppercase superscript letters (A, B, C) within columns do not differ statistically (SNK, p<0.05). Means followed by the same lowercase superscript letters $\left({ }^{a, b}\right)$ within rows do not differ statistically $(\mathrm{SNK}, \mathrm{p}<0.05)$.
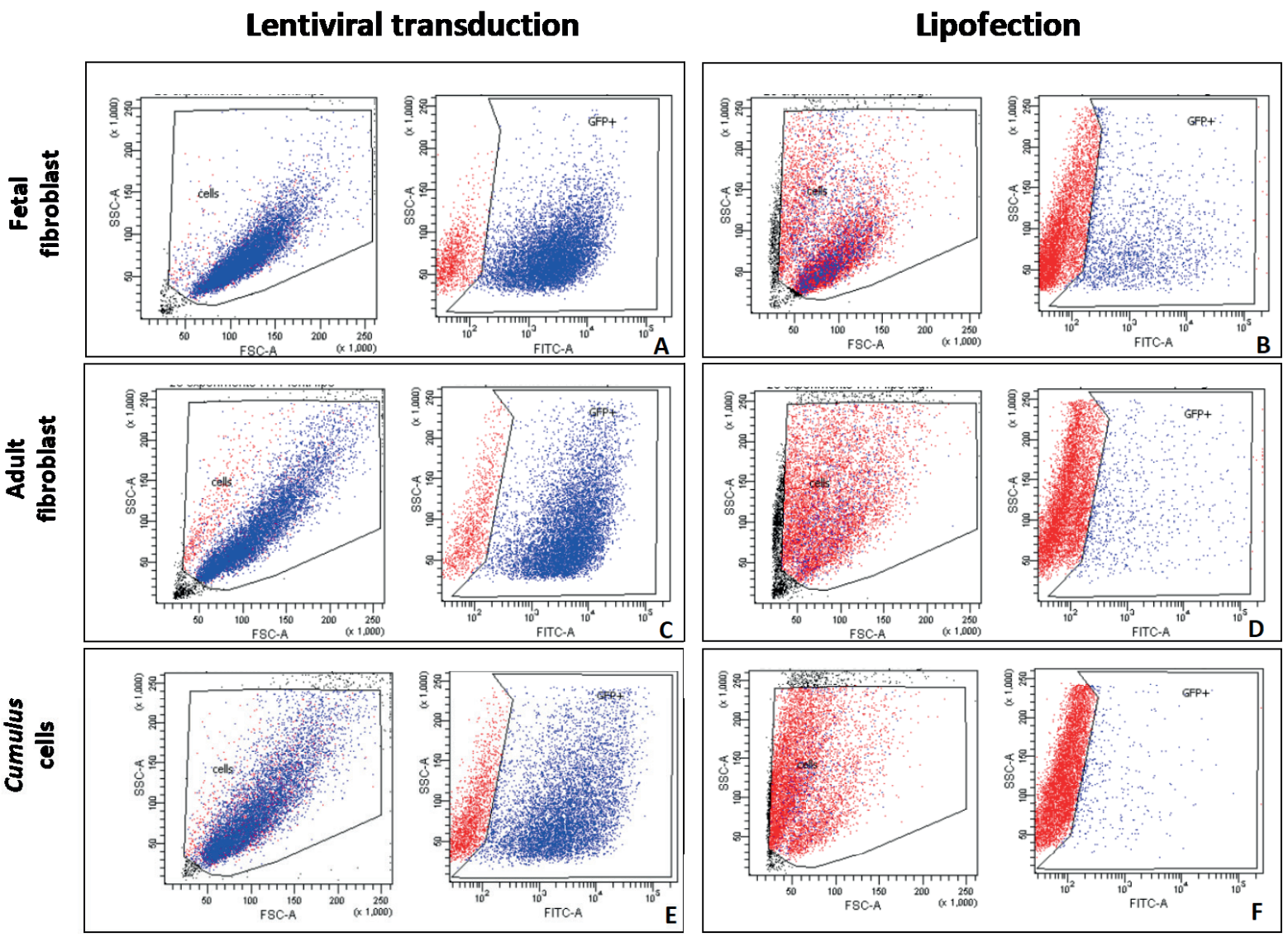

Figure 1. Gene transfer efficiency measured by the number of GFP+ cells (positive cells on FITC channel in FACSAria cytometer) analyzed by flow cytometry. Blue dots refer to cells positive for GFP expression and red dots refer to negative cells. The effects of lentiviral transduction and lipofection, and cell type (rows) on transgene expression in bovine cells were compared. Fluorescence was excited with a 488-nm laser, and read using a 530/30-nm filter. A and B: dotplots for fetal fibroblasts identification (selection FSC-A (size) x SSC-A (complexity)), and fluorescence (SSC-A x FITC-A) after lentiviral transduction and lipofection, respectively. $\mathrm{C}$ and D: dotplots for cell identification and fluorescence for lentiviral transductions and lipofection for adult fibroblasts, and $\mathrm{E}$ and F: dotplots for cell identification and fluorescence for lentiviral transductions and lipofection for cumulus cells. 
Fluorescence intensity, which is related to the expression level of the GFP protein, did not differ significantly $(\mathrm{p}<0.05)$ between lentiviral transduction and lipofection, regardless of the cell type analyzed.
In both treatments, adult fibroblasts showed higher transgene expression levels, which did not differ from those of cumulus cells, but did differ from the fetal fibroblasts $(\mathrm{p}<0.05)$ (Table 2).

Table 2. Fluorescence intensity (arbitrary units) of fetal fibroblasts (FF), adult fibroblasts (AF), and cumulus cells (CC) after lentiviral transduction or lipofection to introduce the plasmid FUGW, as analyzed by flow cytometry.

\begin{tabular}{lccc}
\hline Gene transfer method & FF (Mean \pm SD) & AF (Mean \pm SD) & CC (Mean \pm SD) \\
\hline Lentiviral & $4273 \pm 118.79 \mathrm{Ab}$ & $7957.5 \pm 1120^{\mathrm{Aa}}$ & $6020.5 \pm 310.4^{\mathrm{Aab}}$ \\
Lipofection & $4542 \pm 497.09^{\mathrm{Ab}}$ & $9367.5 \pm 3491^{\mathrm{Aa}}$ & $3496 \pm 2638.9^{\mathrm{Aab}}$ \\
Control & $249 \pm 6.36^{\mathrm{Ba}}$ & $588 \pm 213.54 \mathrm{Ba}$ & $214 \pm 0 \mathrm{Ba}$ \\
\hline
\end{tabular}

Means followed by the same uppercase superscript letters (A, B) within columns do not differ statistically (SNK, $p<0.05)$. Means followed by the same lowercase superscript letters $\left({ }^{a, b}\right)$ within rows do not differ statistically $(S N K, p<0.05)$.

\section{Morphologic evaluation of the post-transfection cells}

At visual assessment, cells submitted to lipofection presented high number of dead cells (detaching debris) per field and presence of cytoplasmic vacuoles. Cumulus cell cultures submitted to Lipofectamine showed the greatest signs of cellular death, with high presence of cytoplasmic vacuoles, cellular debris, and detached cells (Figure 2).

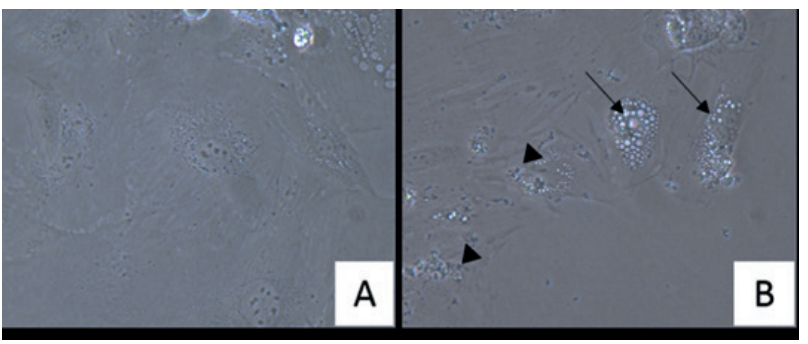

Figure 2. Cumulus cell culture after transfection by lentiviral transduction (A) or Lipofectamine $\mathbb{R} 2000$ (B) observed under light microscopy (200x). Cellular debris (arrowhead) and cytoplasmic vacuoles (arrow) were observed.

\section{Discussion}

The low efficiency of transgenic animal production by SCNT can be attributed to many factors, including the transfection method and the differentiation stage of the donor cell. This study compared the effects of two gene transfer methods, lentiviral transduction and lipofection, and of cell type (AF, FF, and CC) on transgene expression efficiency.

Lentiviral transduction was the most efficient method of gene transfer, differing significantly from lipofection regardless of cell type used and resulting in a high number of $\mathrm{GFP}^{+}$cells per sample. Retroviral vectors are a powerful genetic tool for generation of cells for transgenic animal production, mainly due to the fact that retroviruses use their own biological infection mechanisms to achieve cell transduction, and DNA integration in a stable and lasting method.

The present study used lentiviral vectors, which are able to infect cells which are or are not in division and have the ability to carry out their pre-integration complex in an active manner into the host cell, ensuring DNA integration (Denning et al., 2013). Probably, these factors resulted in the best transgene expression rates when the lentiviral system was used.

On the other hand, when an exogenous DNA sequence is inserted into a mammalian cell through lipofection, the DNA is released into the cell and becomes dependent on the cellular machinery to penetrate the nucleus. The integration into chromosomal DNA is a spontaneous and rare event, which makes the expression, when present, unpredictable (Keravala and Calos, 2008). This fact can explain the lower transfection rates obtained when lipofection was used. Moreover, the use of lipofection has been generally associated with transient transfection (Ooi et al., 2016; Fuge et al., 2017), a fact that limits its application in the production of transgenic animals (Bressan et al., 2008).

Good transfection results have been obtained using lipofection in cellular lineages, such as 293 and HELA cells (Thomas and Smart, 2005; Dalton and Barton, 2014; Vink et al., 2014); however, gene transfer into 
primary culture cells is still limited. Lipofection is a simple and nonviral methodology (Wang et al., 2015), nevertheless, improvement of protocols is needed for individual laboratory conditions, gene construction and type of cell to increase transfection rates and to reduce cell death post-transfection, which was expressive in this study when this transfection method was used.

Cao et al. (2010) compared the gene transfer efficiency ( $p U b-e G F P-F l u c)$ of different gene transfer methods (electroporation, lipofection, nucleofection, and lentiviral transduction) in human embryonic stem cells. They reported that the gene transfer efficiencies of lentiviral transduction and nucleofection were about $25 \%$ higher than those of lipofection and electroporation.

A study using human periodontal ligament stem cells (hPDLSCs) compared transfection efficiency of five nonviral-gene-transfer methods [lipofection using Lipofectamine 2000, polyethylenimine, GBfecteneElite transfection reagent, X-tremeGENE HP DNA Transfection Reagent, and Magnet-Assisted Transfection (MATra)] and lentiviral vectors using fluorescence microscopy and flow cytometry. According to the authors, MATra was the most effective nonviral method reaching around $11 \%$ of transfection, while, the others four nonviral methods, including lipofection, resulted in less than $6 \%$ efficiency. When lentiviral vectors were used, transduction reached about $95 \%$ success. Furthermore, when lipofection reagents were used, the authors also reported cytotoxicity, irregular cell morphology and cells mortality, similar to those observed in the present study (Wang et al., 2015).

In the present study, using fetal fibroblasts, lipofection resulted in about $20 \%$ gene transfer, which was significantly higher than in adult cells subjected to the same treatment. These results may be attributed to cell differentiation status, which is related to the chromatin epigenetic configuration ( $\mathrm{Ng}$ and Gurdon, 2008; Chen and Dent 2014). A more open chromatin configuration, such as that probably found in fetal cells, may be beneficial to the introduction of genes by lipofection, in which the integration to chromosomal DNA occurs spontaneously (Song et al., 2014).

Furthermore, transfection efficiency of lipofection is directly related to cell division rate (Gresch et al.,
2004). In the present work, fetal fibroblasts reached confluence faster than adult cells (data not shown). Such factors can be attributed to the advantage of lipofection when fetal cells are used.

The lentiviral system is well known to result in random and, sometimes, multiple transgene integration events into the host cell DNA. Such fact can increase undesirable DNA integration into encoding sites (Zhang et al., 2012), a problematic issue because position effect variegation can profoundly affect transgene expression, leading to unpredictable transgene expression, including the disruption of endogenous genes, and phenotype (Beard et al., 2006; Rulicke and Hubscher, 2000; Soriano et al., 1987; Williams et al., 2008). Moreover, gene silencing by DNA methylation has been reported due to the presence of viral sequences (Hofmann, 2006). Therefore, previous characterization of cell lines prior to use as donor cells in SCNT is important to guarantee the welfare of transgenic animals (Bressan et al., 2011).

When retroviruses were used in our study, fluorescence intensity -which may be related to the copy number delivery into DNA cells (Soboleski et al., 2005)- did not significantly differ from that obtained with lipofection use; thus, no deleterious effect of retroviral transfection was observed.

To obtain the appropriate expression of a particular protein, the genetic code must be transcribed into the mRNA molecule. Toward this end, a transcription factor recognizes the gene promoter sequence and initiates the mRNA transcription molecule that is translated into the protein. The present work used the FUGW vector (Lois et al., 2002), which contains -besides the coding region for the reporter gene- the GPF; a regulatory posttranscriptional region of the woodchuck hepatitis virus (WRE), introduced to increase the protein transcription level. The human immunodeficiency virus-1 flap was inserted between LTRs to increase viral titers, which are part of the plasmid. Lois et al. (2002) used the human ubiquitin-C promoter in the vector construction. According to Lois et al. (2002), this promoter led to a better transgene expression on the cell types analyzed.

In the present study, it was expected that fetal fibroblasts would present better results since fetal cells are known to be more epigenetically plastic, due 
to its open chromatin status. However, interestingly, adult fibroblasts showed higher fluorescence intensity than fetal fibroblasts in both methods (Table 2). The selection of plasmid construction according to the type of cell seems to be essential for the production of transgenic cells, considering that some promoters are more efficiently expressed in certain tissues than in others (Zheng and Baum 2008), thus leading to different fluorescence levels in different cell types.

Despite the advances in this field, production of transgenic animals by SCNT is still considered a low-efficiency technique (Yang et al., 2008; Bertolini et al., 2016) mainly due to the high number of steps involved in the process from donor cell preparation to transgenic animal birth. The relationships between type and differentiation stage of cells, transfection method, and transgene expression level are not well defined. Further research is needed to understand these relations given that epigenetic factors may be involved and thus may influence the results. To the best of our knowledge, no previous reports or studies have evaluated the effects of transfection method and cell type on transfection rates and transgene expression in cattle. Manipulation of factors responsive for efficiency discrepancies could increase the efficiency of production of transgenic cattle by $\mathrm{TN}$.

In conclusion, gene transfer efficiency differs between cell types depending on the transfection method used. Second, lentiviral transduction resulted in higher transfection rates regardless of cell type. Third, for laboratories without capacities for viral manipulation, lipofection may present an alternative for cell production that transiently expresses transgenes. Finally, although epigenetic profiles may vary between cell lines, and therefore it was expected that fetal lines would be more prone to present a better gene transfer rate, in the conditions of this study the best results were obtained using adult fibroblasts; this could represent an advantage for the production of transgenic animals by nuclear transfer, in which knowledge of animal genotype and phenotype is desired.

\section{Acknowledgments}

This work was supported by Fundação de Amparo à Pesquisa do Estado do Rio de Janeiro (FAPERJ) and
Conselho Nacional de Desenvolvimento Científico e Tecnológico (CNPQ). We also acknowledge colleagues from Universidade de São Paulo (USP) for scientific support.

\section{Conflicts of interest}

The authors declare they have no conflicts of interest with regard to the work presented in this report.

\section{References}

Arat S, Rzucidlo SJ, Gibbons J, Miyoshi K, Stice SL. Production of transgenic bovine embryos by transfer of transfected granulosa cells into enucleated oocytes. Mol Reprod Dev 2001; 60:20-26.

Beard C, Hochedlinger K, Plath K, Wutz A, Jaenisch R. Efficient method to generate single-copy transgenic mice by sitespecific integration in embryonic stem cells. Genesis 2006; 44:23-28.

Bertolini LR, Meade H, Lazzarotto CR, Martins LT, Tavares, KC, Bertolini, M, Murray JD. The transgenic animal platform for biopharmaceutical production. Transgenic Res 2016; 25:329-343.

Bressan FF, Dos Santos Miranda M, Perecin F, De Bem TH, Pereira FT, Russo-Carbolante EM, Alves D, Strauss B, Bajgelman M, Krieger JE, Binelli M, Meirelles FV. Improved production of genetically modified fetuses with homogeneous transgene expression after transgene integration site analysis and recloning in cattle. Cell Reprogram 2011; 13:29-36.

Bressan FF, Miranda M dos S, De Bem THC, Pereira FTVM, Binelli M, Meirelles FV. Production of transgenic animals by nuclear transfer: model for biological studies. Rev Bras Reprod Anim 2008; 32:240-250.

Cao F, Xie X, Gollan T, Zhao L, Narsinh K, Lee RJ, Wu JC. Comparison of gene-transfer efficiency in human embryonic stem cells. Mol Imaging Biol 2010; 12:15-24.

Chen T, Dent SYR. Chromatin modifiers: regulators of cellular differentiation. Nat Rev Genet 2014; 15: 93-106.

Cho J, Bhuiyan, MMU, Shin S, Park E, Jang G, Kang S, Lee B, Hwang W. Development potential of transgenic somatic cell nuclear transfer embryos according to various factors of donor cell. J Vet Med Sci 2004; 66: 1567-1573.

Dalton AC, Barton WA. Over-expression of secreted proteins from mammalian cell lines. Protein Sci 2014; 23:517-525.

Denning W, Das S, Guo S, Xu J, Kappes JC, Hel Z. Optimization of the transductional efficiency of lentiviral vectors: effect of sera and polycations. Mol Biotechnol 2013; 53:08-14.

Feng X, Cao S, Wang H, Meng C, Li J, Jiang J, Qian Y, Su L, He Q, Zhang Q. Production of transgenic dairy goat expressing human $\alpha$-lactalbumin by somatic cell nuclear transfer. Transgenic Res 2015; 24:73-85. 
Fuge G, Zeng AP, Jandt U. Weak cell cycle dependency but strong distortive effects of transfection with Lipofectamine 2000 in near-physiologically synchronized cell culture. Eng Life Sci 2017; 17: 348-356.

Gong G, Dai Y, Fan B, Zhu H, Wang H, Wang L, Fang C, Wan R, Liu Y, Li R, Li N. Production of transgenic blastocyst by nuclear transfer from different types of somatic cells in cattle. Sci China C Life Sci 2004; 47:183-189.

Gresch O, Engel FB, Nesic D, Tran TT, England HM, Hickman ES, Hammermann R. New non-viral method for gene transfer into primary cells. Methods 2004; 33: 151-163.

Hofmann A, Kessler B, Ewerling S, Kabermann A, Brem G, Wolf E, Pfeifer A. Epigenetic regulation of lentiviral transgene vectors in a large animal model. Mol Ther 2006; 13:59-66.

Hsu PD, Lander ES, Zhang F. Development and applications of CRISPR-Cas9 for genome ngineering. Cell 2014; 157:1262-1278.

Jeong YH, Kim YJ, Kim EY, Kim SE, Kim J, Park MJ, Lee HG, Park SP, Kang MJ. Knock-in fibroblasts and transgenic blastocysts for expression of human FGF2 in the bovine $\beta$-casein gene locus using CRISPR/Cas9 nuclease-mediated homologous recombination. Zygote 2016; 24:442-456.

Keravala A, Calos MP. Site-specific chromosomal integration mediated by $\phi C 31$ integrase. Methods Mol Biol 2008; 453:165-173.

Kues W, Niemann H. Advances in farm animal transgenesis. Prev Vet Med 2011; 102: 146-156.

Lois C, Hong EJ, Pease S, Brown EJ, Baltimore D. Germline transmission and tissue-specific expression of transgenes delivered by lentiviral vectors. Science 2002; 295:868-872.

$\mathrm{Ng}$ RK, Gurdon JB. Epigenetic inheritance of cell differentiation status. Cell Cycle 2008 7:1173-7.

Ooi A, Wong A, Esau L, Lemtiri-Chlieh F, Gehring C. A guide to transient expression of membrane proteins in HEK-293 cells for functional characterization. Front physiol 2016; 7:300.

Rulicke T, Hubscher U. Germ line transformation of mammals by pronuclear microinjection. Exp Physiol 2000; 85:589-601.

SAS $^{\circledR}$, Statistical Analysis System. SAS/STAT User's Guide. Version 6.03. Cary, NC, USA: SAS Institute Inc.; 1988.

Sheng J, Wang Y, Turesky RJ, Kluetzman K, Zhang QY, Ding X. Novel transgenic mouse model for studying human serum albumin as a biomarker of carcinogenic exposure. Chemical research in toxicology 2016; 29: 797-809.
Soboleski MR, Oaks J, Halford WP. Green fluorescent protein is a quantitative reporter of gene expression in individual eukaryotic cells. FASEB J 2005; 19:440-442.

Song Y, Hai T, Wang Y, Guo R, Li W, Wang L, Zhou Q. Epigenetic reprogramming, gene expression and in vitro development of porcine SCNT embryos are significantly improved by a histone deacetylase inhibitor--m-carboxycinnamic acid bishydroxamide (CBHA). Protein Cell 2014; 5:382-393.

Soriano P, Gridley T, Jaenisch R. Retroviruses and insertional mutagenesis in mice: proviral integration at the Mov 34 locus leads to early embryonic death. Genes Dev 1987; 1:366-375.

Su J, Zhu L, Sherman A, Wang X, Lin S, Kamesh A., Norikane JH, Streatfield SJ, Herzog RW, Daniell H. Low cost industrial production of coagulation factor IX bioencapsulated in lettuce cells for oral tolerance induction in hemophilia B. Biomaterials 2015; 70:84-93.

Thomas P, Smart TG. HEK293 cell line: a vehicle for the expression of recombinant proteins. J Pharmacol Toxicol Methods 2005; 51:187-200.

Vink T, Oudshoorn-Dickmann M, Roza M, Reitsma J-J, de Jong RN. A simple, robust and highly efficient transient expression system for producing antibodies Methods 2014; 65:5-10.

Wang Y, Shang S, Li C. Comparison of different kinds of nonviral vectors for gene delivery to human periodontal ligament stem cells. J Dental Sci 2015; 10:414-422.

Williams A, Harker N, Ktistaki E, Veiga-Fernandes H, Roderick K, Tolaini M, Norton T, Williams K, Kioussis D. Position effect variegation and imprinting of transgenes in lymphocytes. Nucleic Acids Res 2008; 36:2320-2329.

Yang P, Wang J, Gong G, Sun X, Zhang R, Du Z, Liu Y, Li R, Ding F, Tang B, Dai Y, Li N. Cattle Mammary Bioreactor Generated by a Novel Procedure of Transgenic Cloning for Large-Scale Production of Functional Human Lactoferrin. PLoS ONE 2008; 3:e3453.

Zhang R, Yin Y, Zhang Y, Li K, Zhu H, Gong Q, Wang J, Hu X, Li N. Molecular Characterization of Transgene Integration by Next-Generation Sequencing in Transgenic Cattle. PLoS ONE 2012; 7:e50348.

Zheng C, Baum BJ. Evaluation of promoters for use in tissuespecific gene delivery. Methods Mol Biol 2008; 434:205-219. 